\title{
The Sustainability of Complex Economic Systems. An Application of National Material Flow Analysis (MFA) to the Brazilian Economy
}

\author{
José Alberto da Costa Machado/Norbert Fenzl/Armin Mathis
}

Department of Economy, Social Studies Faculty, Amazonas Federal University,Brazil (Machado) Institute of Advanced Amazonian Studies (NAEA) of the Federal University of Pará (UFPA), Brazil (Fenzl, Mathis) Corresponding Author: Norbert Fenzl, norbert@ufpa.br

\begin{abstract}
A systemic approach to sustainability is suggested where the society-environment relationship is conceived in terms of complex, open systems. The sustainability of the relationship between society and the environment can be analyzed with the help of Material Flow Analysis (MFA). MFA reveals aspects of the economy that concern its relationship to the environment and can't be covered by monetary analyses. In this work material flows and their resulting indicators for the Brazilian economy from 1975 to 1995 are presented. The results show that the Brazilian economy in 1995 became much more intensive in material than in 1975. This development is in line with a global trend of material consumption becoming more intensive and unsustainable. The global economic system has
\end{abstract}

not diminished its size, but expanded its consumption drive in relation to the environment.

\begin{abstract}
Keywords: sustainability, sustainable development, systems theory, open systems, material flow analysis (MFA)

Acknowledgement: Article produced under the Project Amazonia 21, sponsored by the European Union and presented, preliminarily, at the International Conference on Sustainable Regional development in Amazonia: strategies, and instruments, from October 24-27, 2003, in Manaus-Am, Brazil
\end{abstract}

\section{Introduction}

After its initial phase of denouncement and diagnosis, the debate on the sustainability of the relation between society and the environment, seems to have reached maturity with the legitimacy of a methodological matrix known as Material Flow Analysis (MFA). Tested during the nineties by various research institutions ${ }^{1}$, this approach is now formally recognized as a reference by the European Union (EUROSTAT 2001). The results achieved with the use of MFA allow an analysis of the economic system through its material, and not only its monetary flows, as in classic analytical instruments. This permits us to measure the material intensity of the economy, the rationality of natural resource use, and the size of the ecological rucksacks ${ }^{2}$. Such information allows us to know the environmental dimension of economic processes, as well as to formulate sustainability indicators, with a consistent empirical base. In this work, material flows and their resulting indicators for the Brazilian economy from 1975 to 1995 are presented.

\footnotetext{
${ }^{1}$ IFF - Institute of Interdisciplinary Research - Austria, Centre of Environmental Science - Holland, Wuppertal Institute for Climate, Environment and energy - Germany, Nucleo de Altos Estudos Amazônicos, Federal University of Para Brazil and others.

${ }^{2}$ Quantity of material mobilized by the economy and not integrated in the commodities generated by that economy.
} 


\section{Theory, Methods and Materials}

Material Flow Analysis is an analytical method affiliated to systems theory ${ }^{3}$. This theory holds that natural systems ${ }^{4}$ may be categorized ${ }^{5}$, as suggested by Prigogine and Stengers (1984), according to the type of relation developed with their specific environment, that is: isolated systems, which exchange nothing with the environment ${ }^{6}$, closed systems, which only exchange energy ${ }^{7}$, and open systems, which exchange energy and material with its environment. An open system emerges, grows, holds itself in a stationary state, evolves, holds news stationary states and, when it is not able either to maintain such states or to auto-evolve, it perishes. This cycle may be synthesized as follows: (i) in order to guarantee the reproduction of its energy-material metabolism, the system imports both material and energy from its specific environment - its field of interaction; (ii) for this import to occur, the system acts upon its environment in order to mold it according to its needs; (iii) when the system acts to organize its environment importing material and energy, it also 'imports' changes in that environment, which compels it to react through adjustments in its working or structural change parameters; (iv) energy necessary for this permanent behavioural and structural re-adaptation, is the entropy of the system, which, if in excess, may turn its existence unviable.

Thus, the sustainability of an open system, from its performance point of view ${ }^{8}$, depends on the nature of its energy-material metabolism, that is, if its type of reproduction is sustainable or not. The quality of this metabolism energy-material is revealed through observable effects in the environment, in the structural coherence and in the internal elements of the system. These effects need to be perceived by the system, so it may adjust its metabolism.

MFA is a method that allows access to the society-environment relation through the measurement of two main dynamics: the first one, the socioeconomic metabolism, conveys the notion that society extracts resources from the environment through the economic system, processes these resources, and deposits them in the environment in the form of products and waste; the second one, colonization, suggests that society, also mediated by its economic system and aiming at adjusting the environment to its interests, intervenes on it, transforming it to attend to its exclusive necessities, damaging other species. Further reading about this method may be found in Bringezu (2000), Bringezu/Schütz (2001), Fischer-Kowalski (1998, 1999a, 1999b).

Through the study of the socioeconomic metabolism, it is possible to characterize the main material flows that have originated from the society-environment relations. Such flows reveal the material intensity of the economy and, therefore, its sustainability pattern.

For this study, the main conceptual categories used are listed below. The material aggregates associated to these concepts have been calculated, and its indicators have been elaborated and its trends examined during the study-period. Such aggregates are:

- Population: population of the country

\footnotetext{
${ }^{3}$ This theory has been treated as a way of thinking about reality that can only become concrete when associated with a particular field of knowledge, and in these circumstances, it would adjust itself to the rigor and characteristics of the host field. Systems theory, however, is an autonomous knowledge field, with its own orientations, and in relation to other fields, becomes a meta-theory with a particular cosmo-vision.

${ }^{4}$ Although there are systems made by humans, like machinery and software, concepts utilized here refer to natural systems, that is, those which form a part of the functioning of the material and social environment.

${ }^{5}$ When not referenced, the concepts utilized here are based on the following works: Fenzl (1995, 1997), Machado (1998)

${ }^{6}$ Such systems exist because of the energy, which for some reason, is already circulating in their interior. In practice, with the exception of the universe itself, there are no isolated systems.

${ }^{7}$ Earth is an example. It receives solar energy and exports to space unutilized energy or that which escaped from its internal processes

8 There are environmental mutations that appear autonomously in the environment, that also affect the system's sustainability.
} 
- Gross Domestic Product: (GDP.): economic product derived from national accounts;

- Domestic Extraction (DE): the material, used by the economy, that was extracted from of the country's own environment;

- Direct Material Input (DMI): total material used by the economic system. It is calculated by the sum of domestic extraction (DE) and by imported material.

- Domestic Material Consumption (DMC): total material used for the economic system and directed to the country's own economy. It is obtained by subtracting exports from DMI.

- Total Material Input (TMI): total material mobilized by the economic system for its activities. It is calculated by the sum of DMI and the material extracted domestically and not used, that is, material which does not integrate the commodities in the economic system.

Details on the data and its gathering and calculation process may be obtained in Machado (1999).

\section{Results}

The main results and indicators show that:

- Domestic Extraction (DE) in 1975 was 1,081,358 thousand tons, and in 1995 it increased to $2,383,073$, which represents a growth of $120.37 \%$;

- Direct Material Input (DMI) in 1975 was $1.136,020$ thousand tons and in 1995, it increased to $2,476,867$, which represents a growth of $118.03 \%$;

- Domestic Material Consumption (DMC) in 1975 was $1.040,907$ thousand tons, and in 1995 it increased to $2.269,240$, which represents a growth of $118.00 \%$;

- Total Material Input (TMI) in 1975, was 1.706,777 thousand tons, and in 1995 it increased to $3,530,142$, which represents a growth of $106.83 \%$;

One may observe that all aggregate materials had a growth superior, in large scale, to population growth $(47,72 \%)$ and the growth of the GDP $(67,54 \%)$. This means that the Brazilian Economy has an intense and growing demand for material that does not result from factors which can explain such growth (population and GDP growth).

In relation to the indicators, one may observe that:

- DE per capita was 9.9 tons and grew to 14.6; DMI per capita was 10.4 tons and grew to 15.2; DMC per capita was 9.6 tons and grew to 13.9; and TMI per capita was 15.7 tons and grew to 21.6;

- DE per GDP million (DE/Million of GDP) was 2,856 tons and grew to 3,756; DMI per GDP million was 3,000 tons and grew to 3,904 ; DMC per GDP million was 2,749 tons and grew to 3,577 ; TMI per GDP million was 4,507 tons and grew to 5,564 .

When considering per capita consumption, we observe that the absolute growth of material demand was about $46 \%$ in relation to DE, DMI and DMC and $37 \%$ in relation to TMI. When considering consumption per million (\$) of GDP, we observe that absolute growth in demand was about $31 \%$ in relation to DE, DMI and DMC, and $24 \%$ in relation to TMI. The results expressed by these indicators show that in 1995, the Brazilian economy became much more intensive in material than in 1975.

Trends of aggregates and indicators show that there is a consistent growth trend of all indicators. Besides, we see a trend to detach growth of material consumption from GDP and population growth. This suggests that material consumption in Brazil, although influenced by population and GDP growth, has its own dynamic and becomes more intensive and unsustainable.

\footnotetext{
${ }^{9}$ Each concept's acronym is being presented according to international standards. Usually they are formed by the initials of English words.
} 


\section{Conclusions}

Use of quantitative data and easily understood indicators allowed to demonstrate that the Brazilian economy follows the same patterns of industrialized countries, i.e. it strides towards even more unsustainable patterns (Machado/Fenzl 1999). Without political measures and research, such as this, which highlight the material intensity of national economies, the systemic logic of such models will continue to be a great source of environmental impacts.

From this perspective, the results of this study become important for all developing countries, being the source for many of the raw materials with a large demand for industrialized countries, like iron, bauxite, timber, oil, etc. This methodology allows us to calculate the environmental load of exported natural resources in order to benefit other regions of the world.

With the exception of particular missionary efforts, until today the debate about the relation between society and the environment has seen a great display of generous intentions and large political mobilization of organized institutions, and international development agencies. Although all commit themselves to sustainable development, the principle has not been made operational because of the absence of consistent alternatives. MFA is one of the methods that can demonstrate that presently there is an alternative to overcome this obstacle. In addition to that, it has shown that in the last 20 years of debate about sustainability, of research, political conferences, and organized militancy, what we see is that the economic system continues its course of action: It has not diminished, but expanded its consumption drive in relation to the environment. The material intensity is globally increasing, despite the discourse of rationalization of production and "dematerialization" of the global economy, based on services and ICT.

Therefore, it is necessary to search for other ways of measuring the efficiency of economic processes. The system must internalize awareness of material flows moving the global economy. In order to do this, measurement is required and, for this purpose, the methodology used herein has proved to be potent in revealing the particularities and characteristics of the material demands of the economic system. So far MFA is a powerful method to "measure" the degree of unsustainability of an economic system, revealing aspects which are absolutely not covered by a simple monetary view of the economy.

\section{References}

Ackoff, R. L. (1981) Creating the Corporate Future. New York. Wiley.

Ahl, V.IAllen, T.F.H. (1996) Hierarchy Theory. New York. Columbia University Press.

Albers, O. (2001) Zukunftswerkstatt und Szenariotechnik. Schnell und innovative die Unternehmenszukunft gestalten.

Regensburg/Düsseldorf/Berlin. Fit for Business.

Bringezu, Stefan (2000). Material Flow Analysis - an Overview. In: Proceedings of SCOPE Workshop of the Project Material Flow Analysis for Sustainable Resource Management (MFAStoRM), 23-24 November, 2000. Wuppertal. Wuppertal Institute.

Bringezu, Stefan/Schütz, Helmut (2001) Material use indicators for European Union, 1980-1997. Eurostat Working Papers 2/2001/B/2. Brussels. European Comission.

EUROSTAT (Statistical Office of the European Communities) (2001) Economy-wide Material Flow Accounts and Balances with derived Resource Use Indicators. A Methodological Guide. Brussels. EUROSTAT.

Fenzl, Norbert (1995) Conceitos gerais em Teoria de Sistemas. Belém. Núcleo de AltosEstudos Amazônicos / Universidade Federal do Pará. (Notas de aulas proferidas no Curso de Doutorado em Desenvolvimento Sustentável do Trópico Úmido).

Fenzl, Norbert (1997) Estudo de parâmetros capazes de dimensionar a sustentabilidade de um processo de desenvolvimento. In: Ximenes, Tereza (Ed.) (1995) Perspectiva do desenvolvimento sustentável: uma contribuição para a Amazônia 21. Belém. Universidade Federal do Pará / Núcleo de Altos Estudos Amazônicos / Associação de Universidades Amazônicas. 657p. pp.1-31.

Fischer-Kowalski, Marina (1998). Society's Metabolism - The Intellectual History of Material Flow Analysis. Part I: 1860-1970. In: Journal of Industrial Ecology, Vol. 2, No. 1, pp. 61-78.

Fischer-Kowalski, Marina (1999a). Society's Metabolism - The Intellectual History of Material Flow Analysis. Part II: 1970-1998. In: Journal of Industrial Ecology, Vol. 2, No. 4, pp. 107-136. 
Fischer-Kowalski, Marina (1999b) Material Flow Accounting (MFA) Information Package. Vienna. OAR-Regionalberatung GmbH, Amazônia 21 Project. 31 p.

Machado, José Alberto da Costa (1998) A sustentabilidade do desenvolvimento e a expres-são energético material dos processos econômicos. Belém. Universidade Federal do Pará. Núcleo de Altos Estudos Amazônicos. (Projeto de Tese de Doutoramento)

Machado, José Alberto da Costa (1999). A sustentabilidade do desenvolvimento e a demanda material do sistema econômico. Belém. Universidade Federal do Pará. Núcleo de Altos Estudos Amazônicos. (Tese de Doutoramento).

Machado, José Alberto da Costa/Fenzl, Norbert (1999) A sustentabilidade do desenvolvimento e a demanda material da economia: o caso do Brasil comparado ao de paises industrializados. Paper do NAEA, no. 155. Belém. Universidade Federal do Pará. Núcleo de Altos Estudos Amazônicos. 